\title{
Efek Penambahan Jus dan Daun Sirih (Piper bettle linn) Sebagai Aditif Pakan Terhadap Peforma Ayam Petelur
}

\author{
Nining Haryuni ${ }^{1}$, Eko Widodo ${ }^{2}$, Edhy Sudjarwo ${ }^{3}$ \\ ${ }^{1}$ Universitas Nahdlatul Ulama Blitar, ${ }^{2,3}$ Universitas Brawijaya, Malang \\ Email: ${ }^{1}$ niningharyuni@gmail.com, ${ }^{2}$ ekowidodo.ub@gmail.com, \\ 3edhysudjarwo@yahoo.co.id
}

\begin{tabular}{l} 
Tersedia Online di \\
\hline http://www.jurnal.unublitar.ac.id/ \\
index.php/briliant
\end{tabular}

\section{Sejarah Artikel}

Diterima pada 2 Oktober 2017

Disetuji pada 30 Oktober 2017

Dipublikasikan pada 13

November 2017 Hal. 429-433

\section{Kata Kunci:}

piper bettle linn juice, pakan aditif, antibakteri, kinerja ayam petelur.

\section{DOI:}

http://dx.doi.org/10.28926/briliant .v2i4.100

\begin{abstract}
Abstrak: Pengembangan unggas telah dilakukan dalam hal perkembangbiakan, pemberian pakan dan manajemen. Namun, implementasinya masih menghadapi banyak tantangan seperti masalah penurunan produksi. Salah satu penyebab penurunan produksi adalah gangguan kesehatan yang disebabkan oleh bakteri patogen (Salmonella $s p$ dan Escherichia coli). Salah satu cara untuk mengatasi masalah tersebut adalah penggunaan bettle linn Juice sebagai pakan tambahan. Tujuan dari penelitian ini adalah untuk mengetahui pengaruh bettle linn Juice sebagai pakan tambahan terhadap kinerja ayam petelur. Metode yang digunakan adalah uji biologis ayam petelur umur 69 minggu Isa Brown Strain dari 250 ayam petelur, menggunakan Completely Randomized Design (RAL) dengan 5 perlakuan dan 5 ulangan. Hasil penelitian menunjukkan bahwa Piper bettle linn Juice tidak memberikan pengaruh yang signifikan (P> 0,05) terhadap konsumsi pakan dan angka kematian. Mempengaruhi secara signifikan (P $<0,01)$ terhadap Hen Day Production (HDP), berat telur dan Feed Conversion Ratio (FCR).
\end{abstract}

Upaya pengembangan ternak unggas dilakukan untuk perbaikan produksi yang mencakup tiga hal utama yaitu dari segi bibit (breeding), pakan (feeding) dan pengelolaan (management). Akan tetapi dalam kanyataannya masih sulit dicapai karena permasalahan yang terkait penurunan produksi maupun penurunan kualitas. Hal ini salah satunya disebabkan karena Escherichia coli dan Salmonella sp. Infeksi kedua bakteri tersebut pada dasarnya dapat diobati dengan menggunakan antibiotik, akan tetapi ada pengeluaran biaya pengobatan dan dapat menghasilkan residu yang bersifat karsinogenik. Penggunaan antibiotik yang terlalu sering ataupun dosis berlebih dapat menyebabkan pembengkakan pada organ ginjal yang dapat memicu kematian pada ternak.

Pangan asal ternak akan menjadi tidak bermanfaat jika berbahaya untuk kesehatan manusia baik yang disebabkan karena residu antibiotik maupun karena identifikasi adanya bakteri patogen seperti Salmonella sp, Escherichia coli dan lain sebagainya. Penting adanya penjaminan keamanan pangan terutama produk hasil ternak yang dimulai dari proses produksi ( $\mathrm{farm}$ ) diantaranya adalah terhadap residu antibiotik dan cemaran dari Salmonella sp dan Escherichia coli. Salah satu alternatif yang dapat digunakan untuk mengurangi bakteri patogen tanpa menggunakan antibiotik adalah dengan memanfaatkan tanaman herbal. Daun sirih merupakan tanaman herbal yang cukup mudah dan banyak ditemukan serta 
harganya murah. Daun sirih mempunyai fungsi yang hampir sama dengan antibiotik yaitu digunakan sebagai antimikroba dan anti jamur yang kuat. Secara umum daun sirih mengandung minyak atsiri sampai 4,2\% yang bersifat antimikroba karena dapat menghambat pertumbuhan beberapa jenis bakteri antara lain Escherichia coli, Salmonella sp (Reveny, 2011), Streptococcus mutans, Pneumococcus sp (Nugroho, 2003). Bacillus cereus, Listeria monocytogenes (Suliantri dkk., 2008), Streptococcus agalactiae, Staphylococcus epidermidis (Poeloegan $d k k ., 2005$ ).

\section{METODE}

\section{Lokasi dan Waktu Penelitian}

Analisa proksimat pakan dilakukan di Laboratorium PT. Sierad Produced Tbk sedangkan uji biologis dilakukan di Peternakan Bapak Towil Desa Mirigambar Kecamatan Ngunut Kabupaten Tulung Agung. Secara keseluruhan penelitian ini dilakukan mulai Februari 2014 sampai dengan April 2014.

\section{Materi Penelitian}

Materi penelitian ini adalah jus daun sirih yang dibuat dengan imbangan daun sirih dan air 1:4, ayam petelur Strain Isa Brown umur 69 minggu sebanyak 250 ekor dan telur. Pakan yang digunakan adalah pakan komersial SM-204 yang didapatkan dari CV. Ivong Farm yang bekerjasama dengan PT. Sierad Produced Tbk, jagung dan katul.

\section{Metode Penelitian}

Rancangan yang digunakan adalah Rancangan Acak Lengkap (RAL) dengan 5 perlakuan dan 5 kali ulangan setiap ulangan terdiri dari 10 ekor ayam. Apabila terdapat perbedaan pengaruh yang nyata atau sangat nyata dilanjutkan dengan ANOVA. Pemberian jus daun sirih dilakukan dengan mengocorkan jus diatas pakan yang dilakukan setiap pagi. Level pemberian jus daun sirih adalah :

$$
\begin{aligned}
& \mathrm{P} 0=\text { Pakan Basal } \\
& \mathrm{P} 1=\text { Pakan Basal }+5 \mathrm{ml} \text { jus } \\
& \mathrm{P} 2=\text { Pakan Basal }+7,5 \mathrm{ml} \text { jus } \\
& \mathrm{P} 3=\text { Pakan Basal }+10 \mathrm{ml} \text { jus } \\
& \mathrm{P} 4=\text { Pakan Basal }+12,5 \mathrm{ml} \text { jus }
\end{aligned}
$$

Tabel 1 Kandungan Zat Makanan Pakan perlakuan

\begin{tabular}{lc}
\hline \multicolumn{1}{c}{ Zat Makanan } & Jumlah (\%) \\
\hline Kadar Air & 12,37 \\
Protein Kasar & 17,25 \\
Lemak Kasar & 4,84 \\
Serat Kasar & 4,04 \\
Abu & 13,16 \\
\hline
\end{tabular}

Sumber : Analisa proksimat di laboratorium PT. Sierad Produced Tbk

\section{Variabel yang Diamati}

Variabel yang Diamati adalah Konsumsi pakan harian, Hen Day Production (HDP), Berat telur, Feed Conversion Ratio (FCR), Mortalitas. 


\section{HASIL}

Tabel 2 Data Rataan Konsumsi Pakan Harian, Hen Day Production (HDP), Bobot Telur dan Feed Conversion Ratio (FCR)

\begin{tabular}{ccccc}
\hline & \multicolumn{4}{c}{ Rataan Parameter } \\
\cline { 2 - 5 } $\begin{array}{c}\text { Perla } \\
\text { kuan }\end{array}$ & $\begin{array}{c}\text { Konsumsi Pakan } \\
(\mathrm{g} / \mathrm{ekor} / \mathrm{hr})\end{array}$ & HDP $(\%)$ & Bobot Telur $(\mathrm{g})$ & FCR \\
\hline P0 & $112,59 \pm 5,4093$ & $69,48^{\mathrm{a}} \pm 0,4021$ & $58,79^{\mathrm{a}} \pm 1,6794$ & $2,66^{\mathrm{c}} \pm 0,0529$ \\
P1 & $111,29 \pm 2,1424$ & $73,89^{\mathrm{b}} \pm 0,6159$ & $61,45^{\mathrm{b}} \pm 0,5919$ & $2,52^{\mathrm{b}} \pm 0,0663$ \\
P2 & $110,88 \pm 5,7114$ & $75,33^{\mathrm{bc}} \pm 0,9091$ & $61,60^{\mathrm{b}} \pm 1,5001$ & $2,46^{\mathrm{b}} \pm 0,0557$ \\
P3 & $109,42 \pm 4,9669$ & $75,89^{\mathrm{c}} \pm 0,5008$ & $61,55^{\mathrm{b}} \pm 0,9026$ & $2,44^{\mathrm{b}} \pm 0,0519$ \\
P4 & $109,36 \pm 5,6089$ & $76,43^{\mathrm{c}} \pm 1,4417$ & $61,67^{\mathrm{b}} \pm 1,1029$ & $2,33^{\mathrm{a}} \pm 0,0624$ \\
\hline
\end{tabular}

\section{PEMBAHASAN}

\section{Konsumsi Pakan Harian}

Analisis statistik menunjukkan bahwa pemberian jus daun sirih tidak memberikan pengaruh yang nyata $(\mathrm{P}>0,05)$ terhadap konsumsi pakan. Hal ini disebabkan karena kandungan energi dan protein dari semua pakan perlakuan pada penelitian ini adalah sama sehingga konsumsi energi juga akan sama untuk semua perlakuan.

Pakan merupakan sumber utama energi bagi ternak (Bahri dan Rusdi, 2008). Energi pakan berpengaruh terhadap konsumsi pakan, jika energi pakan ditingkatkan maka konsumsinya akan menurun begitu sebaliknya (Yulrahmen, 2013). Konsumsi pakan akan menurun sebesar 1,8\% setiap kenaikan $50 \mathrm{Kkal} / \mathrm{kg}$ pakan (Amrulloh, 2003). Zahra $d k k$., (2012) menyebutkan bahwa konsumsi pakan dipengaruhi oleh beberapa faktor antara lain: umur, palatabilitas pakan, energi pakan, tingkat produksi, kuantitas dan kualitas pakan.

\section{Hen Day Production (HDP)}

Analisis statistik menunjukkan bahwa jus daun sirih hijau memberikan pengaruh yang sangat nyata $(\mathrm{P}<0,01)$ terhadap HDP. Tabel 2 memperlihatkan produksi telur mengalami peningkatan dengan adanya pemberian jus daun sirih. Hal ini disebabkan karena jus daun sirih hijau bersifat antimikroba yang mampu untuk membunuh bakteri patogen didalam saluran pencernaan. Kusumaningsih dan Sudarwanto (2011) menyatakan dalam industri peternakan ayam, antimikroba juga digunakan sebagai imbuhan pakan dengan tujuan untuk meningkatkan produksi telur.

Produksi telur dipengaruhi oleh banyak faktor diantaranya adalah bibit, umur, kondisi kesehatan ayam, perkandangan pencahayaan, pakan, suhu lingkungan (Muharlien, 2010), protein, fosfor (Yulrahmen, 2008), tahap kedewasaan, obat, zat makanan dalam pakan terutama asam amino dan kandungan asam lemak linoleat (Tugiyanti dan Iriyati, 2012).

\section{Bobot Telur}

Analisis statistik menunjukkan penambahan jus daun sirih sebagai aditif pakan memberikan pengaruh yang sangat nyata $(\mathrm{P}<0,01)$ terhadap bobot telur. 
Tabel 2 menunjukkan peningkatan bobot telur seiring dengan penambahan level jus daun sirih. Hal ini disebabkan karena berkurangnya bakteri patogen dalam saluran pencernaan oleh jus daun sirih menyebabkan penyerapan zat makanan termasuk juga protein menjadi optimal. Horhoruw et al., (2009) menyatakan bahwa kandungan protein pada pakan akan mempengaruhi komposisi telur dan bobot telur yang dihasilkan. Menurut Yulrahmen (2008) faktor yang mempengaruhi besarnya telur adalah tingkat dewasa kelamin, protein dan asam amino yang cukup dalam pakan, genetik, tahap kedewasaan umur, obat-obatan dan zat-zat makanan lain dalam pakan.

\section{Feed Conversion Ratio (FCR)}

Analisis statistik menunjukkan bahwa penambahan jus daun sirih dalam pakan memberikan pengaruh yang sangat nyata $(\mathrm{P}<0,01)$ terhadap feed convertion ratio. Hal ini disebabkan karena danya pengaruh yang sangat nyata terhadap HDP dan bobot telur.

Konversi pakan dapat digunakan untuk menduga keuntungan. Semakin rendah konversi pakan, maka hasil yang diperoleh akan semakin menguntungkan (Lokapirnasari, $d k k ., 2011$ ).

\section{Mortalitas}

Angka mortalitas pada penelitian ini adalah $0 \%$ atau tidak ditemukan adanya kematian baik pada pakan kontrol maupun pakan perlakuan. Hal ini mengindikasikan bahwa pakan perlakuan memiliki kualitas yang sama dengan pakan kontrol.

Mortalitas dipengaruhi oleh sistem pemeliharaan khususnya kebersihan dan kesehatan (Nurcholis $d k k$., 2009). Tingginya mortalitas terjadi karena adanya gangguan kesehatan ayam yang disebabkan penyakit. Penelitian Rivai (2001) didapatkan mortalitas yang tinggi karena adanya penyakit tetelo dan pullorum serta adanya kanibalisme. Penelitian Nataamijaya (2008) didapatkan tingkat mortalitas yang tinggi disebabkan oleh infectius coryza akibat infeksi dari Haemophillus gallinarum.

\section{KESIMPULAN}

Kesimpulan dari penelitian ini adalah penggunaan jus daun sirih (Piper bettle linn) pada pakan dapat meningkatkan Hen Day Production (HDP), bobot telur dan menurunkan nilai Feed Conversion Rasio (FCR).

\section{SARAN}

Disarankan untuk melakukan penelitian lebih lanjut untuk mengetahui sampai berapa tingkat kemampuan ayam petelur untuk dapat mentoleransi penggunaan jus daun sirih sebagai aditif pakan.

\section{DAFTAR RUJUKAN}

Amrulloh, I, K. 2003. Nutrisi Ayam Petelur. Bogor: Satu Gunung Budi.

Bahri, S dan Rusdi. 2008. Evaluasi Energi Metabolis Pakan Lokal Pada Ayam Petelur. J. Agroland, 15 (1): $75-78$.

Horhoruw. W.M, Wihandoyo dan Yuwanta. T. 2009. Pengaruh Pemanfaatan Rumput Laut (Gracilaria edulis) Dalam Pakan Terhadap Kinerja Ayam Fase Pullet. Buletin 
Peternakan. 33(1): 8-16.

Kusumaningsih. A dan Sudarwo. M. 2011. Infeksi Salmonella enteritidis Pada Telur Ayam Dan Manusia Serta Resistensinya Terhadap Antimikroba. Bogor: Balai Besar Penelitian Veteriner.

Lokapirnasari. W. P, Soewarno dan Damayanti. Y. 2011. Potensi Crude Spirulina Terhadap Protein Effisiensi Rasio pada Ayam Petelur. Jurnal Ilmiah Kedokteran Hewan. 2(1).

Muharlien. 2010. Meningkatkan Kualitas Telur Melalui Penambahan Teh Hijau Dalam Pakan Ayam Petelur. Jurnal Ilmu dan Teknologi Hasil Ternak. 5(1): 32-37.

Nataamijaya. A.G. 2008. Karakteristik dan Produktivitas Ayam Kedu Hitam. Buletin Plasma Nutfah, 14(2).

Nugroho Trilaksana. 2003. Pengaruh Pemaparan Kombinasi Ekstrak Meniran (Phylanthus niruri linn) dan Ekstrak Sirih (Piper bettle linn) Terhadap Viabilitas Sel Tumor Adenocarcinoma mammae Mencit C3H Secara Invitro. Tesis Tidak diterbitkan. Semarang: Pasca Sarjana Universitas Diponegoro.

Nurcholis, Hastuti. D dan Sutiono.B. 2009. Tatalaksana Pemeliharaan Ayam Ras Petelur Periode Layer Di Populer Farm Desa Kuncen Kecamatan Mijen Kota Semarang. MEDIAGRO. 5(2).

Poeloengan M., Susan dan Andriani. 2005. Efektivitas Ekstrak Daun Sirih (Piper bettle linn) Terhadap Mastitis Subklinis. Bogor: Balai Penelitian Beteriner.

Reveny. J. 2011. Daya Antimikroba Ekstrak dan Fraksi Daun Sirih Merah (Piper betle Linn.). Jurnal ILMU DASAR. 12(1): 6-12.

Rivai. F. 2001. Pertumbuhan Ayam Kampung, Pelung dan Persilangan Pelung Kampung Keturunan Pertama (F1) Umur 5 - 12 Minggu. Skripsi tidak diterbitkan. Bogor: Jurusan Fakultas Peternakan Institut Pertanian Bogor.

Suliantri., A.Apriyanto., M.T.Suhartono dan B.S.L Jenie. 2008. Aktivitas Antibakteri Ekstrak Sirih Hijau (Piper bettle linn) Terhadap Bakteri Patogen Pangan. Jurnal Teknol dan Industri Pangan. 19(1).

Tugiyati. E dan Iriyanti. N. 2012. Kualitas Eksternal Telur Ayam Petelur Yang Mendapat Ransum Dengan Penambahan Tepung Ikan Fermentasi Menggunakan Isolat Produser Anthistamin. Jurnal Aplikasi Teknologi Pangan. 1(2).

Yulrahmen, R. 2008. Performa Ayam Petelur Umur 21-27 Minggu Yang Diberi Air Rebusan Daun Sirih (Piper bettle linn) Pada Air Minum. Skripsi tidak diterbitkan. Bogor: Fakultas Peternakan IPB.

Zahra A.A., D.Sunarti dan E.Suprijatna. 2012. Pengaruh Pemberian Pakan BebasPilih (Free Choice Feeding) Terhadap Performans Produksi Telur Burung Puyuh (Coturnix coturnix japonica). Animal Agricultural Journal. 1: 1-11. 